\title{
Boriding and boronitrocarburising effects on hardness, wear and corrosion behavior of AISI 4130 steel
}

Ramdane Nora ${ }^{1}$, Touhami Mohamed Zine ${ }^{1}$, Khettache Abdelkader ${ }^{2}$, Khelfaoui Youcef ${ }^{3}$, Ourdjini $\mathrm{Ali}^{4}$, Xin Jiang ${ }^{5}$

\footnotetext{
${ }^{1}$ Foundry Laboratory, Department of Metallurgy, University of Badji-Mokhtar, Annaba, Annaba, Algeria.

${ }^{2}$ Laboratory of Physical Metallurgy and Mechanical Properties, Department of Metallurgy, University of Badji-Mokhtar, Annaba, Annaba, Algeria.

${ }^{3}$ Laboratory of Mechanical, Materials and Energy, University of Bejaia, Bejaia, Kabylia, Algeria.

${ }^{4}$ Department of Mechanical Engineering, Faculty of Engineering, University of Ottawa, Ontario, Ontario, Canada.

${ }^{5}$ Chair of Surface and Materials Technology, Institute of Materials Engineering, University of Siegen, Siegen, Arnsberg, Germany.

e-mail: ramdanenora@yahoo.fr,touhamimz23000@gmail.com,khettader@gmail.com,youcef_khelfaoui@yahoo.fr, ali.ourdjini@gmail.com, Xin.Jiang@univ-siegen.de
}

\begin{abstract}
The effects of boriding and boronitrocarburising surface treatments on the microstructure and mechanical properties of AISI 4130 steel have been investigated. Pack boriding was carried out at $1223 \mathrm{~K}$ for $5 \mathrm{~h}$ and 8 $\mathrm{h}$, while the double treatment of boronitrocarburising consisted of salt bath nitrocarburising at $853 \mathrm{~K} \mathrm{for} 6 \mathrm{~h}$ followed by pack boriding at the same temperature and times as the boriding treatment. Microstructure examination of the borided and boronitrocarburised layers was carried out using optical and scanning electron microscopy, and phase identification was obtained using X-ray diffraction. Vickers hardness, wear and corrosion weight loss tests were used to evaluate the mechanical properties and corrosion behaviour. The results of $\mathrm{X}$-ray diffraction analysis revealed the presence of superhard phases such as $\mathrm{FeB}, \mathrm{Fe}_{2} \mathrm{~B}, \mathrm{CrB}, \mathrm{MnB}$ and $\mathrm{MnB}_{2}$, indicating that pack boriding surface treatment conducted at $1223 \mathrm{~K}$ for $8 \mathrm{~h}$ exhibited the highest hardness, low coefficient of friction and the greatest wear resistance. Boronitrocarburising treatment, on the other hand, caused a reduction in both the depth of iron borides zone and mechanical properties compared to the boriding surface treatment. These recommended treatments offer to industrialists a particular contribution and interest in the development of these steels, which can be applied in various fields.
\end{abstract}

Keywords: AISI 4130, Boriding, Boronitrocarburising, Microstructure, Mechanical properties.

\section{INTRODUCTION}

It is well established that nitrocarburising and boriding treatment of steels generate surfaces which causes considerable modification in the mechanical, tribological and corrosion properties [1,2]. Liquid nitrocarburising is a thermochemical treatment in which nitrogen and carbon are supplied simultaneously to ferrous alloy surfaces at temperatures between $823 \mathrm{~K}$ to $853 \mathrm{~K}$, causing the formation of the compound layers $\varepsilon-\mathrm{Fe}_{2-3}(\mathrm{C}, \mathrm{N})$ and $\gamma^{\prime}-\mathrm{Fe}_{4}(\mathrm{C}, \mathrm{N})$ followed by a diffusion zone [3,4]. In general, this compound layer is characterized by a micro-porous structure with the presence of cracks near the surface [5].

Previous research has shown that ferritic nitrocarburising process is considered an effective engineering technology to improve properties such as hardness, fatigue, wear and corrosion resistance [3]. In addition, nitrocarburising surface treatment possesses several advantages compared to other processes, including lower treatment temperature, shorter treatment time, greater degree of shape and dimensional stability besides safety and appreciable reproducibility [6].

Boriding, is a thermochemical diffusion process similar to nitrocarburising in which boron atoms diffuse into the substrate to produce boride layers. The process requires a high treatment temperature (1073$1323 \mathrm{~K}$ ) and long duration (1-12 h), and can be applied to a wide range of materials such as steels, cast iron, cermets, and non-ferrous alloys [7-10]. The process can be carried out in solid, liquid, gaseous or plasma medium. Off all these methods, only paste and pack boriding are currently state-of-the-art and used for commercial purposes. Liquid and gas boriding techniques come along with serious toxicity problems whereas 
plasma boriding might be a sustainable concept for the future. Pack boriding is a low cost surface hardening process, which can be profitably employed to decrease the wear in steel components in moving parts in machinery. The boriding powder is formed mainly of a mixture of $\mathrm{B}_{4} \mathrm{C}$ as an active source and $\mathrm{SiC}$ as inert filler. Added to that, there is a boriding activator such as $\mathrm{KBF}_{4}, \mathrm{Na}_{2} \mathrm{CO}_{3}$ and $\mathrm{Na}_{2} \mathrm{~B}_{4} \mathrm{O}_{7}$ to initiate the reaction. The boriding mixtures that can be marketed are different and for example are: $5 \% \mathrm{~B}_{4} \mathrm{C}+90 \% \mathrm{SiC}+5 \%$ $\mathrm{KBF}_{4}, 85 \% \mathrm{~B}_{4} \mathrm{C}+15 \% \mathrm{Na}_{2} \mathrm{CO}_{3}, 84 \% \mathrm{~B}_{4} \mathrm{C}+16 \% \mathrm{Na}_{2} \mathrm{~B}_{4} 0_{7}[11-13]$.

Boriding of low alloy steels usually leads to the formation of two types of iron borides based on the Fe-B phase diagram. The outer layer consists of $\mathrm{FeB}$ with an orthorhombic crystal structure and the inner layer of $\mathrm{Fe}_{2} \mathrm{~B}$ with characteristic saw-tooth morphology having a tetragonal crystal structure. Boride layers formed on steel surfaces exhibit high hardness, high abrasive wear resistance and excellent corrosion resistance [14]. The thickness of iron borides depends on the method of boriding treatment, temperature and time of process and their morphology is influenced by the alloying elements present in the substrate [15]. However, the main drawback of iron borides is that they are brittle, especially the FeB phase. Furthermore, since $\mathrm{FeB}$ and $\mathrm{Fe}_{2} \mathrm{~B}$ borides have different coefficients of thermal expansion, cracks often form on the $\mathrm{FeB} / \mathrm{Fe}_{2} \mathrm{~B}$ interface. The properties of boride layers are usually superior to those formed by nitriding and carburising, particularly in terms of their hardness (1600-2300 HV for boriding compared to 650-900 HV for nitriding and carburising) [16]. For so many years, researchers have shown great interest in the conventional thermochemical treatments owing to their importance to industry. However, combining these different surface treatments offers the possibility of modifying the chemical composition of the surface layers by forming superhard phases which precipitate on the extreme surface and diffusion zone.

These combined treatments improve the lifetime of the machine components by reducing wear, corrosion, surface roughness, and coefficient of friction. To the best of the author's knowledge, very little work has envisaged the combination between these complex surface treatments on steels namely boronitriding [17, 18], borocarburising [14-19] and borocarbonitriding [20]. In addition, there is a lack of research available that has dealt with combining between surface treatments of nitriding, nitrocarburising and boriding of steels [21, 22]. Therefore, the present research has been conducted with the main objective being the enhancement of the surface properties of AISI 4130 alloy steel. This material is used for many applications such as automotive, machine tools, aerospace, hydraulic tools, agricultural and defense industries etc. This steel is subjected to a duplex treatment of nitrocarburising and boriding, comparison with untreated, nitrocarburised and borided samples is also made. The microstructure, phases evolution, microhardness profiles, and the distribution of N, C, O and B in boride layers from the surface towards the core of the steel substrate have been investigated. Wear test has also been carried out to investigate the effect of the different surface treatments on the coefficient of friction, surface roughness and wear rate.

\section{MATERIALS AND METHODS}

The substrate used in this study is an AISI 4130 alloy steel supplied by ETRAG - Company- Constantine (Algeria) with the following chemical composition (wt.\%): $0.202 \mathrm{C}, 0.226 \mathrm{Si}, 1.288 \mathrm{Mn}, 1.221 \mathrm{Cr}, 0.470 \mathrm{Mo}$, $0.019 \mathrm{P}, 0.038 \mathrm{~S}$ and $\mathrm{Fe}$ as the balance. Prior to the surface treatment, the samples were prepared in sizes of $15 \times 15 \times 10 \mathrm{~mm}$. Before nitrocarburising, the flat surface of each sample was grind using emery paper 320, 500 and 800 grit size. The temperature for liquid nitrocarburising is lower than Fe-N eutectoid point (approximatively $864 \mathrm{~K}$ ) according to the phase diagram. Liquid nitrocarburising is carried out in a molten salt bath consisting of $60 \% \mathrm{KCN}, 24 \% \mathrm{KCl}$, and $16 \% \mathrm{~K}_{2} \mathrm{CO}_{3}$ by weight [23]. The standard temperature is usually $580^{\circ} \mathrm{C}[24,25]$ and the diffusion time taken in our case is $6 \mathrm{~h}$.

The boriding treatment was performed in a solid medium using the powder pack method in steel boxes, which were filled with a granular boriding agent consisting of the boriding source, $\mathrm{B}_{4} \mathrm{C}(85 \%)$ and the activator $\mathrm{Na}_{2} \mathrm{CO}_{3}(15 \%)[13,26]$. A large contact surface is desired between the samples and boriding agent to allow for a better diffusion of Boron atoms into the substrate surface. The packed boxes were placed in the preheated electrical resistance furnace and cooled in air. The pack boriding process was performed according to the experimental plan shown in Table 1. 
Table 1: Surface treatment parameters and sample designation.

\begin{tabular}{c|l}
\hline Sample & Treatment parameters \\
\hline SA & Annealing $1123 \mathrm{~K} / 1 \mathrm{~h} /$ air cooling \\
\hline NC & Nitrocarburising $(853 \mathrm{~K} / 6 \mathrm{~h})$ \\
\hline B1 & Pack boriding $(\mathrm{T}=1223 \mathrm{~K} / 5 \mathrm{~h})$ \\
\hline B2 & Pack boriding $(\mathrm{T}=1223 \mathrm{~K} / 8 \mathrm{~h})$ \\
\hline DT1 & Nitrocarburising + boriding $(1223 \mathrm{~K} / 5 \mathrm{~h})$ \\
\hline DT2 & Nitrocarburising + boriding $(1223 \mathrm{~K} / 8 \mathrm{~h})$ \\
\hline
\end{tabular}

After the surface treatments, cross-sections of the specimens were prepared for microstructure examination according to standard metallographic procedures. First, they were ground using silicon carbide paper and then subjected to final polishing with diamond paste having the particle size of $1 \mu \mathrm{m}$. After ultrasonic cleaning in ethanol, samples were etched in a 3\% Nital etching solution. The thickness and morphology of the layers were determined using BX51M Olympus microscope and a Zeiss Ultra TM55 type scanning electron microscope. The distribution of elements as function of the depth from the surface was determined by means of energy dispersive X-ray spectroscopy (EDS). Phase identification was carried out using X-ray diffraction (XRD) analysis by a diffractometer (Bruker D8 Advance Model) with $\mathrm{CuK}_{\alpha}$ radiation $\left(\lambda_{\mathrm{Cu}}=0.145\right.$ $\mathrm{nm}$ ) and operated at $45 \mathrm{kV}$ and $35 \mathrm{~mA}$. A $2 \theta$ angles ranging from 10 to $120^{\circ}$ achieved in symmetric conditions and a grazing incidence angle of $1^{\circ}$ was chosen for all measurements. Only, for the case of the nitrocarburised sample (NC), we took $2 \theta$ angles between $15^{\circ}$ and $118^{\circ}$. In order to evaluate the hardness distribution profiles, microhardness measurements were made on the polished cross-sections using a microhardness tester (Shimadzu HMV-2000) with a load of $0.1 \mathrm{Kgf}$ for a dwell time of $15 \mathrm{~s}$. The values of the microhardness are the average of three indentations in order to ensure reproducibility of the hardness data. To perform friction of test materials, a Tribometer module/Version 4.4.U was used. All tests were performed at ambient conditions without lubrication. A $6 \mathrm{~mm}$ radius $\mathrm{Al}_{2} \mathrm{O}_{3}$ ball pin was used as counterpart to the rotating sample and the applied normal load was $10 \mathrm{~N}$ with a sliding velocity of $0.1 \mathrm{~m} . \mathrm{s}^{-1}$. The surface roughness was measured using Mitutoyo Surftest SJ-301 type equipment. For corrosion tests, the samples were immersed in $10 \%$ $\mathrm{H}_{2} \mathrm{SO}_{4}$ solution for $160 \mathrm{~h}$ at room temperature. After every $6 \mathrm{~h}$, the samples were washed in running water and acetone and then dried. An analytical microbalance (Ohaus standard precision) with an accuracy of $10^{-3} \mathrm{~g}$ was used to measure weight changes and calculate the corrosion rate.

\section{RESULTS AND DISCUSSION}

\subsection{Characterisation of nitrocarburised and borided layers}

The microstructure of the AISI 4130 steel nitrocarburised at $853 \mathrm{~K}$ for $6 \mathrm{~h}$ is shown in Figure 1 . It is characterized by the presence of an outer compound layer consisting of a mixture of $\varepsilon-\mathrm{Fe}_{3} \mathrm{~N}$ and $\gamma^{\prime}-\mathrm{Fe}_{4} \mathrm{~N}$, with a thickness of around 18-25 $\mu \mathrm{m}$. Many works have shown that a ferritic nitrocarburising process gives the compound layer consisting essentially of $\varepsilon-\mathrm{Fe}_{2-3}(\mathrm{C}, \mathrm{N})$ and $\gamma^{\prime}-\mathrm{Fe}_{4}(\mathrm{C}, \mathrm{N})$ associated with porosity $[27,28]$.In this zone, $\mathrm{N}$ and $\mathrm{C}$ atoms are dissolved interstitially in the ferritic lattice and form nitride precipitates [28]. Beneath this compound layer is the diffusion layer with a thickness of about 200-230 $\mu \mathrm{m}$ (Table 2). The presence of $\varepsilon-\mathrm{Fe}_{3} \mathrm{~N}$ or/ $\mathrm{Fe}_{2-3}(\mathrm{C}, \mathrm{N})$ and $\gamma^{\prime}-\mathrm{Fe}_{4} \mathrm{~N}$ phases are confirmed by XRD results (Figure 2). Moreover, XRD results also show that the nitrocarbursing treatment results in the formation of $\mathrm{Fe}_{2} \mathrm{O}_{3}$ thin layer in the outer surface as can be ascertained by the XRD pattern. 


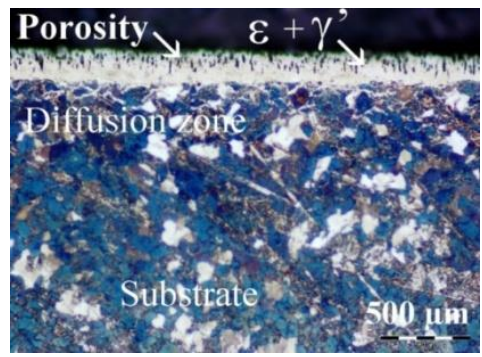

Figure 1: Optical micrograph of cross section of AISI 4130 steel subjected to nitrocarburising surface.

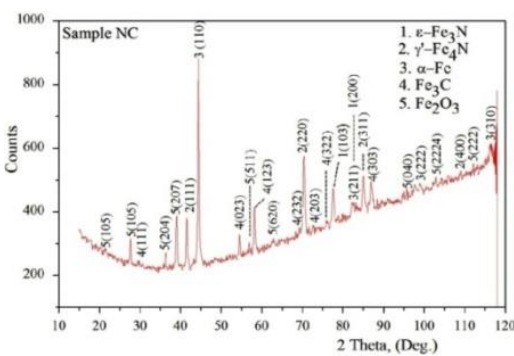

Figure 2: XRD patterns of AISI 4130 steel subjected to nitrocarburising surface treatment.

Figure 3a-3b show the optical micrographs of samples borided at $1223 \mathrm{~K}$ for $5 \mathrm{~h}$ and $8 \mathrm{~h}$ respectively. It is seen that the boride layers exhibited a dual-layered structure, with an outer-dark layer of FeB and an innerbright layer of $\mathrm{Fe}_{2} \mathrm{~B}$. The boriding treatment also caused the formation of a sub-layer zone corresponding to pearlitic transformation and a transition zone between the boride layer and the substrate [29]. This indicates that, during the boriding, carbon diffused away from the boride zone to the matrix. These results confirm previous observations on both redistribution of carbon and the boride morphology in low alloy steels $[30,31]$.

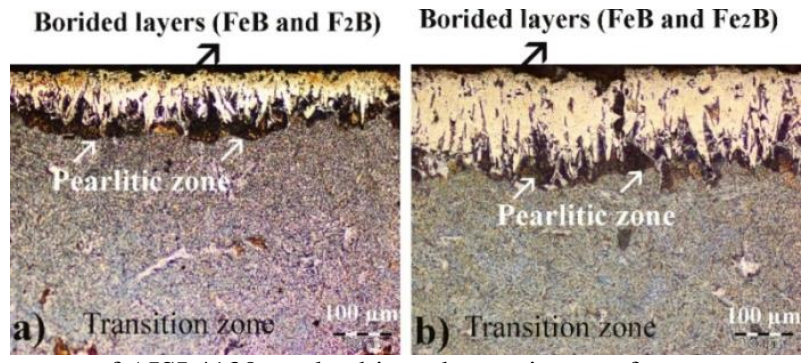

Figure 3 (a,b): Optical microstructures of AISI 4130 steel subjected to various surface treatments.

(a) boriding at $1223 \mathrm{~K} / 5 \mathrm{~h}(\mathrm{~B} 1)$, (b) boriding at $1223 \mathrm{~K} / 8 \mathrm{~h}(\mathrm{~B} 2)$.

It is clear from these micrographs that with increasing treatment time from $5 \mathrm{~h}$ to $8 \mathrm{~h}$, the thickness of boride layers increased. However, it was observed that the increase in the process time did not cause any change in the thickness of the $\mathrm{FeB}$ layer, but had a considerable effect on the $\mathrm{Fe}_{2} \mathrm{~B}$ layer and transition phases. Results of the measured thickness of boride layers are shown in Table 2. The thickness was found to be $70-120 \mu \mathrm{m}$ for sample B1 (pack boriding at $1223 \mathrm{~K}$ for $5 \mathrm{~h}$ ) and $165-205 \mu \mathrm{m}$ for sample B2 (pack boriding at $1223 \mathrm{~K}$ for $8 \mathrm{~h}$ ). Figure 4 shows the SEM micrograph of the dominantly boride layers having a saw tooth morphology that is typical of borided low alloy steels. This type of morphology is necessary for good adhesion between the boride layer and substrate. In addition, the boride morphology is a characteristic property and depends on the concentration of alloying elements as well as the process temperature and time. The FeB layer and the needle-like $\mathrm{Fe}_{2} \mathrm{~B}$ are clearly highlighted in the SEM cross-sectional micrograph. The boriding medium and its composition $\left(85 \% \mathrm{~B}_{4} \mathrm{C}+15 \% \mathrm{Na}_{2} \mathrm{CO}_{3}\right)$ appear to be suitable for the diffusion of more boron into the surface causing an increase in boride layer thickness with increased process time [26]. Figure 5 shows the distribution profile of boron, carbon, oxygen and manganese. The intense manganese peak observed in the Fe-B sub-layers confirms the precipitation of the $\mathrm{MnB}_{2}$ hardening phase. For sample $\mathrm{B} 2$, the dominant phases which formed in the coating layer are $\mathrm{FeB}, \mathrm{Fe}_{2} \mathrm{~B}, \mathrm{CrB}, \mathrm{MnB}, \mathrm{Fe}_{3} \mathrm{C}$ and $\mathrm{MnB}_{2}$. The high amount of boron which diffuses during the boriding process $(1223 \mathrm{~K} / 8 \mathrm{~h})$ and the presence of $\mathrm{Mn}$ in the steel (1.288 wt.\%) led to the formation of $\mathrm{MnB}_{2}$ compound as can be identified in the XRD diffraction pattern in Figure 6a. The $\mathrm{MnB}_{2}$ compound has an hexagonal $\mathrm{AlB}_{2}$-type structure and is predicted to be a superhard material with a hardness of $44 \mathrm{GPa}$ [32]. Thus, the precipitation of $\mathrm{MnB}_{2}$ compound in the boride layers could be responsible for the hardening of the extreme surface of the borided AISI 4130 steel. Furthermore, the $\mathrm{MnB}_{2}$ compound was not observed to form in the sample borided at $1223 \mathrm{~K}$ for $5 \mathrm{~h}$ (Figure $6 \mathrm{~b}$ ). 
Table 2: Results of layer thickness for the treated samples.

\begin{tabular}{l|l|cccc}
\hline \multirow{2}{*}{ Sample } & \multicolumn{2}{|c|}{ Treatments parameters } & \multicolumn{4}{c}{ Layer thickness, $(\boldsymbol{\mu m})$} \\
& & $\varepsilon+\gamma^{\prime}+\mathbf{D Z}$ & $\mathbf{F e B}$ & $\mathbf{F e}_{2} \mathbf{B}$ & TZ \\
\hline SA & Annealing $1123 \mathrm{~K} / 1 \mathrm{~h} /$ air cooling & - & - & - & - \\
\hline NC & Nitrocarburising $(853 \mathrm{~K} / 6 \mathrm{~h})$ & $218-255$ & - & - & - \\
\hline B1 & Pack boriding $(\mathrm{T}=1223 \mathrm{~K} / 5 \mathrm{~h})$ & & $20-30$ & $50-90$ & $400-550$ \\
\hline B2 & Pack boriding $(\mathrm{T}=1223 \mathrm{~K} / 8 \mathrm{~h})$ & - & $15-25$ & $150-180$ & $800-880$ \\
\hline DT1 & Nitrocarburising + boriding at $1223 \mathrm{~K} / 5 \mathrm{~h}$ & - & $10-30$ & $15-75$ & $150-200$ \\
\hline DT2 & Nitrocarburising + boriding at $1223 \mathrm{~K} / 8 \mathrm{~h}$ & - & $20-30$ & $130-160$ & $290-320$ \\
\hline
\end{tabular}

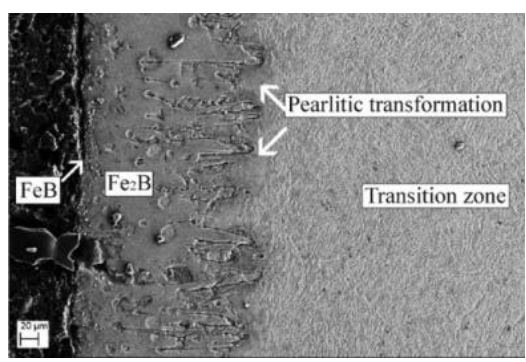

Figure 4: SEM micrographs showing the morphology of layers in borided sample at $1223 \mathrm{~K} / 8 \mathrm{~h}$.

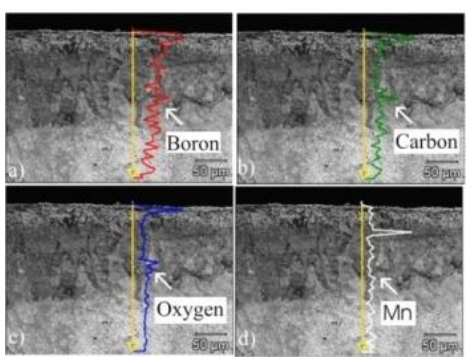

Figure 5(a-d): Distribution profiles of boron carbon,oxygen, and manganese from the surface to the interior of sample (B2).

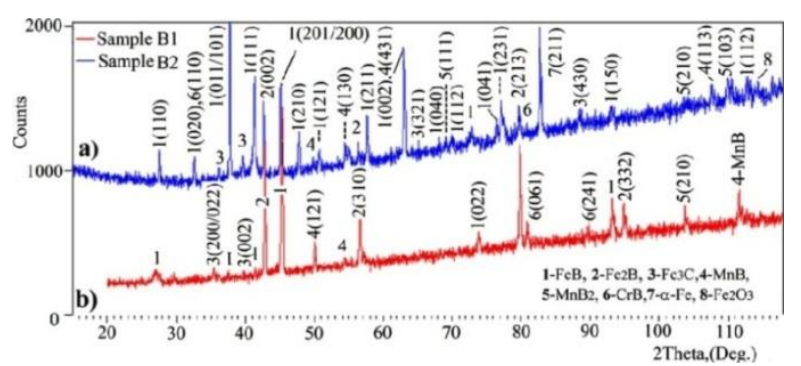

Figure 6: XRD patterns of AISI 4130 steel subjected to the various surface treatments: a) sample B2. b) sample B1.

\subsection{Characterization of boronitrocarburised coatings}

Referring to the anterior results in this study, the mechanism of formation of boronitrocarburised layers, a perlitic transformation as well as the transition zone can be described as follows:

The boriding treatment of samples nitrocarburised induced a dissociation of the nitrides layers $\varepsilon$ - $\mathrm{Fe}_{2-3}$ $(\mathrm{C}, \mathrm{N})+\gamma^{\prime}-\mathrm{Fe}_{4}(\mathrm{C}, \mathrm{N})$ and completely solutionizing of nitrogen and carbon atoms in solid solution. Moreover, the transformation of pearlite-ferrite to austenite occurs and then after a sufficiently long time a homogeneous austenite is formed. During slow cooling, the stable austenite is transformed in giving a zone pearlitic and transition zone corresponding to a transformation bainitic characterized by fine microstructure and a precipitation of borides and carbides such as: $\mathrm{FeB}, \mathrm{Fe}_{2} \mathrm{~B}, \mathrm{CrB}, \mathrm{MnB}, \mathrm{Fe}_{3} \mathrm{C}$. However, during the boriding process at high temperature in a medium rich in boron induces diffusion of boron. The boriding process consists of two reactions. The initial stage takes place between boron medium and component surface. The nuclei are formed as the function of boriding temperature and time and are followed by the growth of boride layer [33]. In case of ferrous materials [34, 35], $\mathrm{Fe}_{2} \mathrm{~B}$ nuclei are first formed and grown a thin boride layer at the defect points of the metal surface, macro-defects (surface roughness, scratches, etc.) and micro-defects (grain boundaries, dislocation, etc.). If the active boron medium is excess, the rich boron product phase, such as $\mathrm{FeB}$, will form and grow on the $\mathrm{Fe}_{2} \mathrm{~B}$ phase.

The second stage is a diffusion-controlled process, which the thickness of boride layer is formed depending on the temperature, and the boriding time [34]. In case of ferrous materials, boron atoms prefer to diffuse in the [001] crystallographic direction and form the body-centered tetragonal lattice of $\mathrm{Fe}_{2} \mathrm{~B}$ to achieve the maximum atomic density along this direction [34,35]. The growth of $\mathrm{Fe}_{2} \mathrm{~B}$ is columnar aggregates of crystals, which exhibits the saw-tooth morphology. For the double phase, the columnar growth of FeB prefers to grow in the [002] crystallographic direction and the saw-tooth structure of FeB is lower than that of $\mathrm{Fe}_{2} \mathrm{~B}$. The cross-section optical micrographs of the boronitrocarburised AISI 4130 steel at the temper- 
ature of $1223 \mathrm{~K}$ for $5 \mathrm{~h}$ and $8 \mathrm{~h}$ are shown in Figure $7 \mathrm{a}$ and Figure $7 \mathrm{~b}$ respectively.

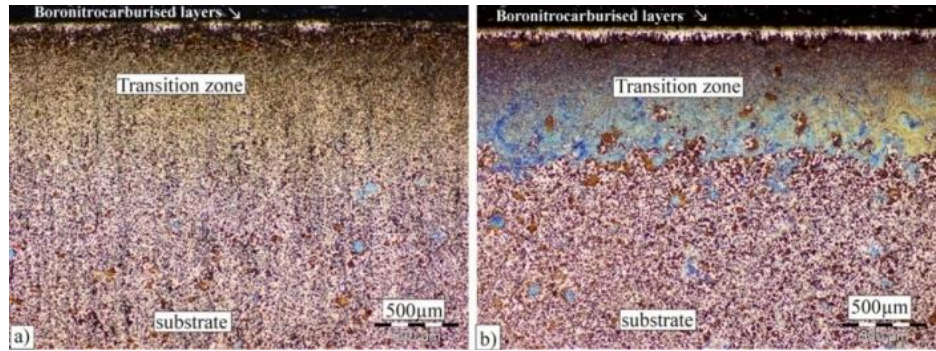

Figure 7 (a,b): Optical microstructures of AISI 4130 steel subjected to various surface treatments.

a) Duplex treatment (DT1). b) Duplex treatment (DT2).

It is very interesting to compare the morphology of the boride layers in sample DT2, which was subjected to boronitricarburising for longer time of $8 \mathrm{~h}$ with the sample DT1 treated for $5 \mathrm{~h}$ at the same temperature. This comparison is illustrated by the SEM micrograph in Figures $8 \mathrm{a}-8 \mathrm{~b}$ and clearly shows that the borides layers formed on AISI 4130 steel exhibit saw tooth morphology. The figures also show the presence of an almost completely pearlitic zone beneath the boride layer, which indicates that during the boriding process; carbon diffuses away from the boride zone into the substrate. Since carbon does not dissolve significantly in $\mathrm{FeB}$ and $\mathrm{Fe}_{2} \mathrm{~B}$ layers, it is driven ahead of the boride layer forming a poly-phase zone rich in carbides and borocarbides as $\mathrm{Fe}_{3}(\mathrm{~B}, \mathrm{C})$ between the $\mathrm{Fe}_{2} \mathrm{~B}$ sublayer and the substrate [36, 37]. The diffusion time generates formation of boride layers $\mathrm{FeB}$ and $\mathrm{Fe}_{2} \mathrm{~B}$, with variation in the thickness of $\mathrm{Fe}_{2} \mathrm{~B}$ layer being more significant than in the FeB layer as shown clearly in Table 2.
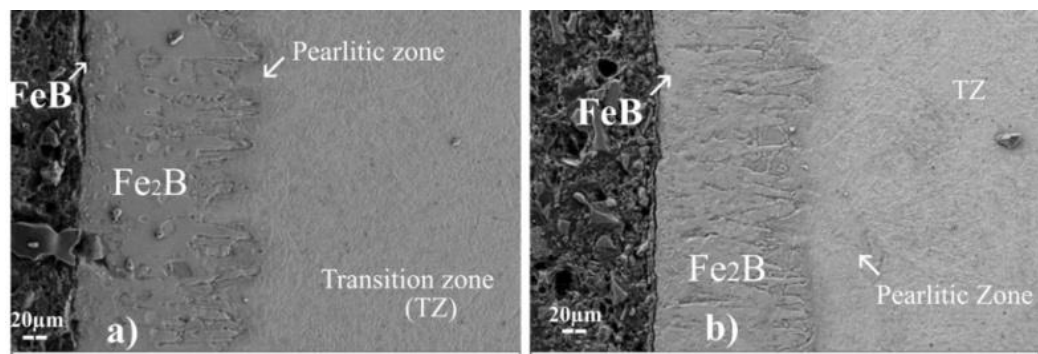

Figure 8 (a,b): SEM Micrographs showing the morphology of layers in boronitrocarburised samples, a) DT1. b) DT2.

Results of XRD analysis show the formation of $\mathrm{FeB}, \mathrm{Fe}_{2} \mathrm{~B}, \mathrm{CrB}, \mathrm{MnB}, \mathrm{Fe}_{3} \mathrm{C}$, and $\mathrm{Fe}_{2} \mathrm{O}_{3}$ phases in sample DT2 (Figure 9a). It was also observed that the $\mathrm{MnB}_{2}$ phase has not formed in the DT1 and DT2 samples that were subjected to the duplex treatments of nitrocarburising and boriding, due to the amount of boron (Figure 9b). According to Darnley et al. [38], the alloying elements (except nickel, cobalt, and manganese), which retard the boron diffusion into the substrate, is to increase the proportion of FeB constitution and the thickness of the boride layer is reduced and its hardness increases [20].

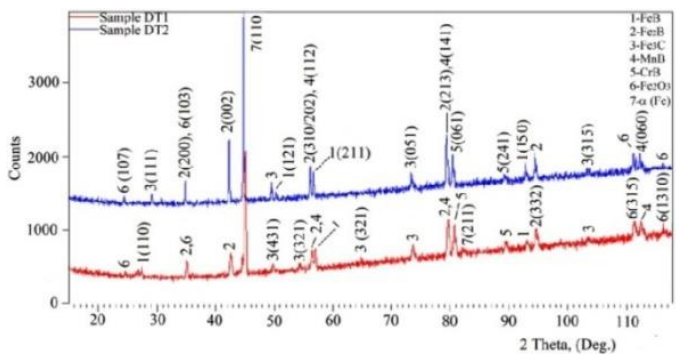

Figure 9: XRD patterns of AISI 4130 steel subjected to the various surface treatments.

a) sample DT2 b) sample DT1. 
However, it was found that duplex treatment (DT2) caused a reduction of the thickness of boride layers which is mainly due to the effect of nitrogen and carbon (Figure 10). The intense peaks of carbon and nitrogen observed in the Fe-B layers explain that these layers impede the diffusion of boron and consequently the diffusion leads to the decreasing of thickness of boride layer and the increasing of the smooth boride layer/substrate interface [15]. Figure 10 show the distribution profiles of boron, carbon, oxygen, nitrogen from the surface to the interior of samples. The results confirm the presence of boron throughout the hardened layer in the sample which was subjected to the duplex treatment (DT2) as well as elements of carbon, nitrogen and oxygen that result from the nitrocarburising treatment only. Kunst et al. [39] have reported that oxygen probably plays an active role in the boron transfer mechanisms in that large excesses of oxygen in the pack furnace atmosphere have been discovered to accelerate boride layer growth and inhibit porosity. The increase in the amount of oxygen generated the formation of iron oxide layer $\left(\mathrm{Fe}_{2} \mathrm{O}_{3}\right)$ which limited the diffusion of boron and consequently the boronitrocarburised layer thickness. These results are in good agreement with those found in the literature $[22,40]$.

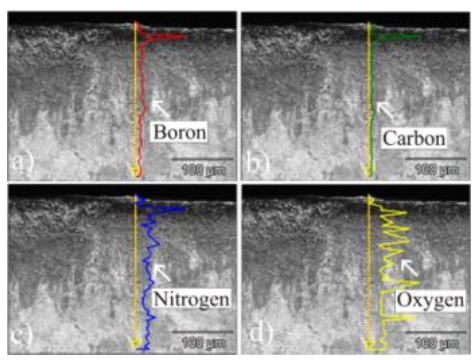

Figure 10 (a-d): Distribution profiles of boron, carbon, nitrogen and oxygen from the surface to the interior of sample (DT2).

\subsection{Microhardness}

Figure 11 shows the microhardness profiles obtained from the cross-sections of the various treated samples. It is seen that all samples exhibit high values of microhardness at the surface and then decreases when we move towards the interior of substrate. For the sample NC (nitrobarburising at $853 \mathrm{~K}$ for $6 \mathrm{~h}$ ), a low value of microhardness of the iron nitrides zone of $580 \mathrm{HV}_{0.1}$ was obtained at the surface, which is probably due to the presence of pores in the compound layer (Figure 3). Although the nitrocarburized layers are porous, they exhibit excellent surface properties such as roughness, wear resistance and friction coefficient. According the literature, the modification of steel surface by salt bath nitrocarburising improves surface hardness, fatigue strength, wear and corrosion resistance [4,28]. When the AISI 4130 steel was subjected to the boriding treatment, the hardness values increased significantly, particularly when the diffusion time increased from $5 \mathrm{~h}$ to 8 h. Indeed, higher hardness $2340 \mathrm{HV}_{0.1}$ was obtained in the sample B2, while for the sample B1, the hardness is $2030 \mathrm{HV}_{0.1}$. This increase in hardness is due to the diffusion of boron to form precipitates such as chromium boride $(\mathrm{CrB})$, manganese boride $(\mathrm{MnB})$, and the superhard phase $\mathrm{MnB}_{2}$ which are found in the hard phases of $\mathrm{FeB}$ and $\mathrm{Fe}_{2} \mathrm{~B}[10,41]$.

In the samples treated by the double processes of boriding and nitrocarburising, lower values of microhardness profile from with increasing depth the iron boride zone to the substrate compared to the hardness values measured in the borides layers. Indeed, hardness values of $1300 \mathrm{HV}$ and $1600 \mathrm{HV}_{0.1}$ were obtained at the surface in DT1 and DT2 samples respectively. The decrease in the hardness values compared to the boride layers can be explained by the high contents of carbon and nitrogen which prevent the growth of boronitrocarburised layers. The results obtained in this study are in good agreement with those reported by Kulka et al. [20], who showed that borocarbonitriding process reduces the depth of iron boride zone and consequently reduces the microhardness across the case. 


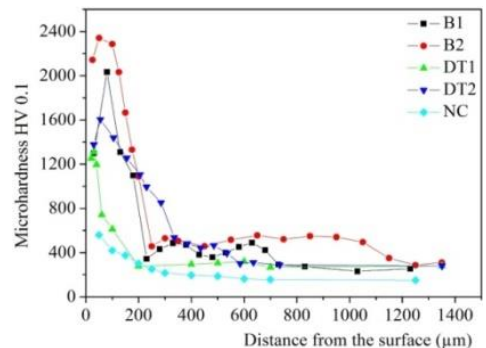

Figure 11: Microhardness profiles as function of depth from the hardened layers in AISI 4130 steel subjected to the various treatments.

\subsection{Wear and friction}

Figure 12 shows the average coefficients of friction of untreated, nitrocarburised, boronised and boronitrocarburised samples obtained under dry conditions (Table 3). The coefficient of friction of the untreated sample (SA) was found to be 0.8 compared to the lower value of 0.58 for the nitrocarburised sample (NC). The low surface properties observed in the case of the sample (SA) are directly related to the microstructure formed mainly by ferrite and pearlite which that does not stand up in aggressive media like sulfuric acid $\left(10 \% \mathrm{H}_{2} \mathrm{SO}_{4}\right)$ and the high friction coefficient is a function of the surface roughness.

The fact that the nitrocarburised sample exhibited lower coefficient of friction is due to the formation of a thin layer of $\mathrm{Fe}_{2} \mathrm{O}_{3}$ as the outermost layer on top of the compound layer during cooling of nitrocarburised surfaces. This thin layer of $\mathrm{Fe}_{2} \mathrm{O}_{3}$ is more resilient and also contributes to the covering of the hard porous compound layer and as a result provides lower friction and thus a lower wear rate.

For the boronised sample B2, it was observed that when the treatment time is increased from $5 \mathrm{~h}$ to $8 \mathrm{~h}$ the surface roughness is increased to $1.39 \mu \mathrm{m}$ and the coefficient of friction was found to be very low (0.27), and which remained constant during the entire sliding test. The surface-roughness values of the boronitrocarburised samples (DT1 and DT2) varied from 2.20 to $2.76 \mu \mathrm{m}$. It has been demonstrated by Gunes and al. [42], that the values of surface roughness increase with an increase in the values of boride layer thickness, also the surface roughness is very sensitive to the time of boriding [43].

The results of weight loss of the NC, DT1 and DT2 samples after immersion in a solution of 10\% $\mathrm{H}_{2} \mathrm{SO}_{4}$ at ambient temperature for up to $160 \mathrm{~h}$ are illustrated in Figure 13. During the immersion test of all the samples, we recorded for the first times weight gain related to the formation of a thin layer on the surfaces. This layer begins to deteriorate according to the immersion time and the weight loss is announced gradually until the end of the test. It is clearly seen that the least corrosion weight loss was observed in the sample subjected to the boriding treatment at $1223 \mathrm{~K} / 8 \mathrm{~h}$ producing the lowest reduction of weight loss, corrosion rate and low friction coefficient. This applied treatment caused excellent surface properties compared to other treatments. These results of pack boriding are consistent with previous research [10, 44, 45]. Both nitrocarburised and boronitrocarburised samples showed similar corrosion behaviour with the same corrosion rates (Table 3). According Maragoudakis et al. [18], the duplex surface treatment carried out on boronitrided steel exhibited excellent adherence and morphology. It is well known that thin layers reduce the level of residual stresses and the cracking risk thus the flaking phenomenon.

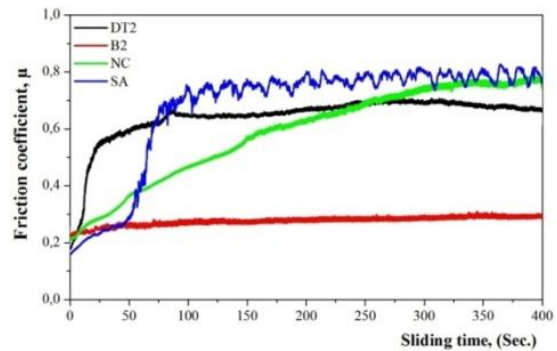

Figure 12: Friction coefficients versus sliding time of samples SA, NC, B2, DT2.

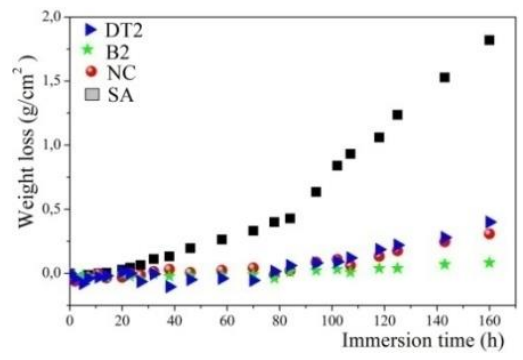

Figure 13:Weight loss of immersion tests of samples SA,NC, B2, DT2. 
Table 3: Results of coefficient of friction and corrosion rates.

\begin{tabular}{c|c|c|c|c}
\hline Sample & $\begin{array}{c}\text { Weight loss } \\
\left(\mathbf{g} \cdot \mathbf{c m}^{-2}\right)\end{array}$ & $\begin{array}{c}\text { Corrosion rate } \\
\left(\boldsymbol{g} \cdot \mathbf{~ c m}^{-2}\right) \text { per day }\end{array}$ & $\begin{array}{c}\text { Roughness } \\
\mathbf{R a}(\boldsymbol{\mu m})\end{array}$ & $\begin{array}{c}\text { Average of friction } \\
\text { coefficient }(\boldsymbol{\mu})\end{array}$ \\
\hline SA & 1.820 & 0.254 & - & 0.80 \\
\hline NC & 0.308 & 0.041 & 0.72 & 0.58 \\
\hline B2 & 0.083 & 0.011 & 1.39 & 0.27 \\
\hline DT2 & 0.40 & 0.046 & 2.76 & 0.64 \\
\hline
\end{tabular}

\section{CONCLUSIONS}

The effect of duplex surface treatment of nitrocarburising followed by boriding on microstructure, wear and corrosion properties has been investigated. Comparison with untreated, nitrocarburised and borided AISI4130 steel samples have been made. The following conclusions were drawn:

1. Surface treatment of the 4130 steel by boriding exhibited the lowest coefficient of friction and wear as well as the lowest corrosion rate compared to nitrocarburised and duplex treatment of boronitrocarburised steels.

2. Increasing boriding treatment diffusion time from $5 \mathrm{~h}$ to $8 \mathrm{~h}$ produced thicker boride layers and induced formation of superhard phases such as $\mathrm{FeB}, \mathrm{Fe}_{2} \mathrm{~B}, \mathrm{CrB}, \mathrm{MnB}$ and $\mathrm{MnB}_{2}$, generating high hardness, low coefficient of friction and low corrosion weight loss.

3. The presence of nitrogen and carbon had a considerable effect on the boronitrocarburised layers formation, reducing their thickness and hardness

4. Boronitrocarburising surface treatment caused a reduction in both depth of iron borides and hardness. Wear rate of the boronitrocarburised layers was approximatively 5-6 times greater than that of the untreated samples.

5. Combined treatment has a positive influence on the reduction of the thickness and decreases considerably the flaking risk and increase the adhesion of the layers which constitute for industry a favorable asset for the mechanical parts.

\section{ACKNOWLEDGMENTS}

The authors wish to thank the ETRAG-company-Constantine for the salt bath nitrocarburising treatment applied to the samples. All the thanks to the staff of Surface and Materials Technology, University of Siegen (Germany) for their technical and scientific support.

\section{BIBLIOGRAPHY}

[1] SILVA, Z., ORTIZ-DOMINGUEZ, M., KEDDAM, M., et al., "Boriding kinetics of $\mathrm{Fe}_{2} B$ layers formed on AISI 1045 steel”, Journal of Mining and Metallurgy,Section B-Metallurgy, v.50, pp.101-107, 2014.

[2] BALIKLI, E., YAMAN, O., "Investigation on liquid bath nitriding of selected steels", Surface Engineering,v.27, pp. 609-615, 2011.

[3] PANTAZOPOULOS, G., PSYLLAKI, P., "An Overview on the tribological behaviour of nitrocarburised steels for various industrial applications”, Tribology International,v. 37, pp. 299-308, 2015.

[4] GAGANDEEP S., GURBHINDER B., , "Modification of EN9 steel surface by salt bath nitrocarburising process", Journal of Materials Science and Surface Engineering, v.5, n. 4, pp. 577-580, 2017.

[5] PANTAZOPOUlOS, G., ANTONIOU, S., "Wear-Related Failures of Nitrocarburized Steels: Some Microstructural and Morphological Observations", Journal of Failure Analysis and Prevention ,v.4,n.6, pp. 51-57, 2004.

[6] FARES,M.L., TOUHAMI, M.Z., BELAID, M., BRUYAS, H., "Surface characteristics analysis of nitrocarburised (Tenifer) and carbonitrided industrial steel AISI 02 types”, Surface and Interface Analysis,v. 41, pp. 179-186, 2009.

[7] KAYALI, Y., "Investigation of diffusion kinetics of borided AISI P20 steel in microwave furnace", Vaccum,v. 121, pp.129-134, 2015. 
[8] WANG,H., LU, W.Z., XU, J., et al., "Effect of rare earth on pack boronising process of titanium alloy", Surface Engineering,v. 30, pp. 123-128, 2014.

[9] ELIAS-ESPINOSA, M., ORTIZ DOMÍNGUEZ, M., KEDDAM, M., et al., "Boriding kinetics and mechanical behaviour of AISI 01 steel”, Surface Engineering, v. 30, pp. 490-497, 2014.

[10] ERDOGAN, M., GUNES, I., "Corrosion Behaviour and microstructure of Borided Tool Steel”, Materia, v.20, pp.1-7, 2015.

[11] AZOUANI, O., KEDDAM,M., ALLAOUI,O., et al., "Characterization of boride coatings on a ductile cast iron", Protection of Metals and Physical Chemistry of Surfaces,v. 53, n.2, pp. 306-311, 2017.

[12] KUL, M., OSKAY, K.O., TEMIZKAN, A., et al., "Effect of boronizing composition on boride layer of boronized GGG-60 ductile cast iron",v.126, pp.80-83, 2016.

[13] YORULMAZ, M.A., An investigation of boriding of medium carbon steels, $\mathrm{PhD}$ thesis, University of Marmara, Istanbul,Turkey, 2007.

[14] KULKA, M., MAKUCH, N., DZIARSKI, P., et al., "Gradient boride layers formed by diffusion carburising and laser boriding", Optics and Lasers in Engineering, v. 67, pp.163-175, 2015.

[15] BEKTES, M., CALIK, A., UCAR, N., et al., "Pack-boriding of the Fe-Mn binary alloys: Characterization and kinetics of the boride layers", Materials Characterization, v.61, pp. 233-239, 2010.

[16] MATIJEVIÇ, B., "Evaluation of boride layer growth on carbon steel surfaces", Metal Science and Heat Treatment, v.56, pp. 269-273, 2014.

[17] GŎMEZ-VARGAS, O. A., SOLIS-ROMERO, J., FIGUEROA-LŎPEZ, U., et al., "Boronitriding coating on pure iron by powder-pack boriding and nitriding processes", Materials Letters, v.176, pp. 261264, 2016.

[18] MARAGOUDAKIS, N.E., STERGIOUDIS, G., OMAR, H., et al., "Boro-nitriding of steel US37-1", Materials Letters, v. 57, pp. 949-952, 2002.

[19] WANG, B., JIN, X., XUE, W., et al., "High temperature tribological behaviors of plasma electrolytic borocarburised Q235 low-carbon steel”, Surface Coatings and Technology, v. 232, pp.142-149, 2013.

[20] KULKA, M., PERTEK A., "Characterisation of complex $(\mathrm{B}+\mathrm{C}+\mathrm{N})$ diffusion layers formed on chromium and nickel -based low-carbon steel", Applied Surface Science, v. 218, pp.113-122, 2003.

[21] MINDIVAN, H., "Effects of combined diffusion treatments on the wear behaviour of hardox 400 steel", Procedia Engineering, v. 68, pp.710-715, 2013.

[22] KUSMANOV,S.A., TAMBOVSKIY,I.V., NAUMOV,A.R., et al., "Anode plasma electrolytic boronitrocarburising of low-carbon steel", Surface Engineering and Applied Electrochemistry,v. 51, pp. 462-467, 2015.

[23] PANTAZOPOULOS, G., ANTONIOU, S., "Wear-related failures of nitrocarburized steels: Some microstructural and morphological observations", Journal of Failure Analysis and Prevention, v. 4, n.6, pp. 5157, 2004.

[24] FERNANDES, F.A.P., LAMBARDI NETO, A., CASTELETTI, L.C., et al., "Stainless steel improvement by ion nitriding and nitrocarburising", Heat Treating Progress, pp.41-43, 2008.

[25] CAJNER, F., LANDEK, D., STUPNIŠEK LISAC, E., "Improvement of properties of steels applying salt bath ntrocarburising with post-oxidation”, Materiali in Technologue, v. 37, n.6, pp. 333-336, 2003.

[26] KUL, M., OSKAY, K.O., TEMIZKAN, A., et al., "Effect of boronising composition on boride layer of boronised GGG-60 ductile cast iron", Vaccum, v.126, pp.80-83, 2016.

[27] MITTEMEIJER, E.J., "Fundamentals of nitriding and nitrocarburizing", ASM HANDBOOK, v.4A, Steel Heat Treating Fundamentals and Processes, pp.621, 2013.

[28] VÁZQUEZ, A.,RAMÍREZ, A.L.JUÁREZ, J.A., "Microstructural evaluation of salt nitrocarburizing H13 steel as a function of time", In: VIII International Congress of Engineering Physics,IOP Conf.Series: Journal of Physics: Conf.Series, n.792, pp.1-6, 2017.

[29] ANDRIJANA, M., DRAGOMIR, K., RADOJKA, M., "An investigation of boride layers growth kinetics on carbon steels", Tehnički vjesnik, v. 19, n.1, pp.27-31, 2012.

[30] GOEURIOT, P., FILLIT,R., THEVENOT,F., et al.,"The influence of alloying element additions on the boriding of steels", Materials Science and Engineering, v.55, pp.9-19, 1982.

[31] GOPALAKRISHNAN, P., SHANKAR, P., PALANIAPPA, M., et al., "Interrupted Boriding of Medi- 
um-Carbon Steels", Metallurgical and Materials Transactions A,v. 33A, pp.1475-1485, 2002.

[32] GOU, H., STEINLE-NEUMANN, E., BYKOVA, G., et al., "Stability of $\mathrm{MnB}_{2}$ with $\mathrm{AlB}_{2}$-type structure revealed by first-principles calculations and experiments", Applied Physics Letters, v. 102, pp.1-5, 2013.

[33] CHATTERJEE-FISCHER, R., "Boriding and Diffusion Metallizing", Surface Modification Technologies, New York,Marcel Dekker Inc, 1989.

[34] PALOMBARINI, G., CARBUCICCHIO, M., "On the morphology of thermochemically produced Fe28/Fe interfaces”, Journal of Material Science Letter, v.3, pp.791-794, 1984.

[35] PALOMBARINI, G., CARBUCICCHIO, M., "Growth of bride coatings on iron", Journal of Material Science Letter, v.6, pp.415-416, 1987.

[36] BRAKMAN, C.M., GOMMERAS, A.W.J., MITTEMEIJER, E.J., "Boronizing of $\mathrm{Fe}$ and $\mathrm{Fe}-\mathrm{C}, \mathrm{Fe}-\mathrm{Cr}$ and Fe-Ni alloys; boride -layer growth kinetics", Journal of Materials Research, v.4, pp.1354-1370, 1989.

[37] BADINI, C., GIANOGLIO, C., PRADELLI, G., "The effect of carbon, chromium and nickel on the hardness of boride layers", Surface and Coatings Technology, v.30, pp.157-170, 1987.

[38] DARNLEY, P. A., BELL, T., "Engineering the surface with boron based materials", Surface Engineering, v.1, n.3, pp.203-217, 1985.

[39] KUNST, H., SCHAABER, O., Hiirterei-Tech. Mitt., v.26, n.1, pp.18-20, 1971.

[40] YANIAN, Z., WENKUI, W. F., "Analysis of the layers forming processes of boronizing and nitrocarburizing", Transaction of Materials and Heat Treatment, v.4, pp. 28-34, 1993.

[41] GENCER, Y., "Influence of manganese on pack boriding behaviour of pure iron, Surface Engineering", v.27, pp. 634-638, 2011.

[42] GUNES, I., KAYALI, Y., ULU, S., "Investigation of surface properties and wear resistance of borided steels with different $\mathrm{B}_{4} \mathrm{C}$ mixtures", Indian journal of engineering and materials sciences, v.19, pp.397-402, 2012.

[43] GUNES, I., YILDIZ I., "Investigation of adhesion and tribological behavior of borided AISI 310 stainless steel”, Matéria (Rio J.), v.21, n.1, pp.61-71, 2016.

[44] SU, Z. G. X., TIAN, J. An., LU, Y., et al., "Investigation on boronising of 80 tube steel", Journal of the Iron and Steel Institute of Japan, v.49, pp. 1776 -1783, 2009.

[45] ARUN, S., SIVAKUMAR,T., VISWANATHAN, P., et al., "Study of hardness and wear properties of boronised AISI 4340 steel", International Journal of Engineering and Applied Reserach, v.3, pp.1927-1929, 2013.

\section{ORCID}

Ourdjini Ali

Touhami Mohamed Zine

Khelfaoui Youcef

Khettache Abdelkader

Ramdane Nora

Xin Jiang https://orcid.org/0000-0003-1236-9473

https://orcid.org/0000-0002-7689-4202

https://orcid.org/0000-0003-4586-0584

https://orcid.org/0000-0002-3648-9069

https://orcid.org/0000-0001-9815-1568

https://orcid.org/0000-0002-0396-971X 